A. Mitsyk, V. Fedorovich, A. Grabchenko, Kharkiv, Ukraine

\title{
THE EFFECT OF A SHOCK WAVE IN AN OSCILLATING WORKING MEDIUM DURING VIBRATION FINISHING-GRINDING PROCESSING
}

\begin{abstract}
The propagation of a force pulse in a working medium is considered as in a pseudo-gas, that is, the speed of sound. The movement of parts in the working medium is determined. The mechanism of the appearance of a weak shock wave, that is, a jump of the compaction in a pseudo-gas from abrasive granules is considered. The nature of the interaction of the surfaces of vibrating processed parts with granules of the working medium has been established. The characteristic of the Hugoniot adiabatic curve for pseudo-gas from granules of the working medium is given. The influence of the occurrence of a shock wave on the vibration treatment process is determined. The adequacy of theoretical and experimental studies has been established.
\end{abstract}

Key words: vibration treatment; working medium; processed parts; force impulse; shock wave; kinetic energy; thermodynamic parameters.

The application of the kinetic theory of gases and the equations of gas dynamics to describe the process of vibration finishing-grinding processing of parts made it possible to explain the movement of the working medium granules circulating in the reservoir of the vibrating machine. The speed of sound as the speed of propagation of disturbances in gas is one of the main characteristics of a gas [1].

With multi-energy technology of vibration treatment, the working medium made of abrasive granules is influenced not only by the walls of the vibrating machine reservoir, but also by the surface of the processed parts [2,3]. Such a combined effect not only increases the mobility of abrasive granules, but can also lead to interference propagating from the walls of the vibrating machine reservoir, pseudo-waves and pseudo-gas disturbances from the moving surfaces of parts.

When a body moves in gas at a speed to close or exceeding the speed of sound, a phenomenon occurs that is associated with the impossibility of transmitting a force impulse caused by the movement of the body at a speed greater than the speed of sound. This phenomenon is called a weak shock wave or shock wave [4].

To describe the processes accompanying the supersonic motion of processed parts in reservoir, we introduce the Mach number for pseudo-gas from abrasive granules $-M_{A}$ :

$$
M_{A}=A_{d} \omega_{d} / C=A_{d} \omega_{d} / C_{V} 0.745 A \omega .
$$

Here $A_{d}, \omega_{d}, \omega$ are the amplitude and frequencies of vibrations of parts and walls of the vibrating machine reservoir. 
Continuity equations $-\frac{\partial \rho}{\partial t}+\operatorname{div}(\rho \bar{V})=0$ when a jump occurs in the onedimensional case can be written as follows:

$$
\rho_{1} v_{1}=\rho_{2} v_{2} \text {. }
$$

Here $\rho_{1}, \rho_{2}, v_{1}, v_{2}$ are the densities and velocities before and after the shock wave. This means that on the shock wave surface the values of density and gas velocity undergo a discontinuity. However, their production is continuous. At the same time, in the regions before and after the jump, the values of pressure and speed of movement are also continuous.

Neglecting viscosity and mass forces (gravity), we can write the Navier Stokes equation in the one-dimensional case before and after the shock wave in the following form:

$$
P_{1}+\rho_{1} v_{1}^{2}=P_{2}+\rho_{2} v_{2}^{2} .
$$

The total energy of a small volume of pseudo-gas for abrasive granules of the working medium is equal to $\rho\left(V^{2} / 2+\varepsilon\right) d U$. Here $\varepsilon$ is the internal energy of the gas.

The change in the total energy of the gas is equal to the heat flux passing through the surface of the selected volume due to thermal conductivity, as well as to the work of surface forces acting on the volume, and due to the work of mass forces. Based on this, we can write the equation for the change in the total gas energy in the form:

$$
\frac{d}{d t} \int_{U} \rho\left(V^{2} / 2+\varepsilon\right) d U=-\int_{S} Q_{n} d S+\int_{U} \rho F V d U+\int_{S} P_{n} V d S .
$$

Here $Q_{n}$ is the heat flux perpendicular to the surface of the small volume. For an ideal gas, the internal energy is equal to $\varepsilon=\rho C_{P} T$.

Neglecting heat fluxes and mass forces, it is possible, using equation (3), to write expressions for the total pseudo-gas energies of the medium granules before and after the shock wave in the following form:

$$
\frac{1}{\mu} C_{P} T_{1}+\frac{v_{1}^{2}}{2}=\frac{1}{\mu} C_{P} T_{2}+\frac{v_{2}^{2}}{2} .
$$

Here $\mu$ is the molar mass of the gas. Equation (5) can be converted to:

$$
\frac{\gamma}{\gamma-1} \cdot \frac{P_{1}}{\rho_{1}}+\frac{v_{1}^{2}}{2}=\frac{\gamma}{\gamma-1} \cdot \frac{P_{2}}{\rho_{2}}+\frac{v_{2}^{2}}{2} .
$$


Here $\rho_{1}, \rho_{2}, v_{1}, v_{2}, P_{1}, P_{2}, T_{1}, T_{2}$ - pressures and temperatures before and after the shock wave, $\mu, C_{p}, \gamma-$ molar mass of gas, isobaric heat capacity, Poisson adiabatic exponent. For pseudo-gas from abrasive granules (monoatomic gas) $\gamma=5 / 3$.

Combining expressions (3) - (6), we obtain a dependence connecting the pressure and density of the pseudo-gas in the volume of the oscillating working medium being in undisturbed and disturbed by the movement of parts. In the theory of shock waves in gas, this dependence is called the Hugoniot adiabatic curve [5]:

$$
\frac{P_{2}}{P_{1}}=\frac{(\gamma+1) \rho_{2}-(\gamma-1) \rho_{1}}{(\gamma+1) \rho_{1}-(\gamma-1) \rho_{2}} .
$$

The densities of the pseudo-gas after the shock wave and before it are related to the Mach number by the following relationship:

$$
\frac{\rho_{2}}{\rho_{1}}=\frac{(\gamma+1) M^{2}}{(\gamma+1) M^{2}+2} .
$$

The relationships between the temperature and pressure before and after the shock wave with the Mach number are:

$$
\begin{gathered}
\frac{P_{2}}{P_{1}}=\frac{2 \gamma M^{2}-(\gamma-1)}{(\gamma+1)} ; \\
\frac{T_{2}}{T_{1}}=\frac{\left[2 \gamma M^{2}-(\gamma-1)\right] \cdot\left[(\gamma-1) M^{2}+2\right]}{(\gamma+1)^{2} M^{2}} .
\end{gathered}
$$

Unlike gas molecules, the impact of an abrasive granule on the surface of parts is not absolutely elastic. Part of the energy of the abrasive movement is spent on surface deformation and metal removal. The amount of kinetic energy loss can be estimated by the recovery factor. With this in mind, expression (5) can be written as follows:

$$
\frac{1}{\mu} C_{P} T_{g 1}+\frac{v_{1}^{2}}{2}=\frac{\alpha}{\mu} C_{P} T_{g 2}+\frac{v_{2}^{2}}{2} .
$$

Taking into account the correction for energy loss due to friction, the basic equations (7) - (10) take the following form:

Hugoniot adiabatic curve or shock adiabat: 


$$
\frac{P_{g 2}}{P_{g 1}}=\frac{(\gamma+1) \rho_{g 2}-(\gamma-1) \rho_{g 1}}{\left(\gamma\left(2 \alpha^{2}-1\right)+1\right) \rho_{g 1}-(\gamma-1) \rho_{g 2}} .
$$

Pressure ratio before shock and after shock wave:

$$
\begin{aligned}
\frac{P_{g 2}}{P_{g 1}} & =1-\frac{\gamma\left\{\alpha^{2}-M^{2}\left[\gamma\left(\alpha^{2}-1\right)+1\right]\right\}}{\left[\gamma\left(2 \alpha^{2}-1\right)+1\right]}+ \\
& +\sqrt{\frac{\gamma^{2} M^{2}\left(\alpha^{2}-1\right)}{\left[\gamma\left(2 \alpha^{2}-1\right)+1\right]}+\frac{\gamma^{2}\left\{\alpha^{2}-M^{2}\left[\gamma\left(\alpha^{2}-1\right)+1\right]\right\}^{2}}{\left[\gamma\left(2 \alpha^{2}-1\right)+1\right]^{2}}} .
\end{aligned}
$$

The ratio of the densities of the pseudo-gas before and after shock wave:

$$
\begin{aligned}
\frac{\rho_{g 1}}{\rho_{g 2}} & =1+\frac{\left\{\alpha^{2}-M^{2}\left[\gamma\left(\alpha^{2}-1\right)+1\right]\right\}}{M^{2}\left[\gamma\left(2 \alpha^{2}-1\right)+1\right]}- \\
& -\sqrt{\frac{\left\{\alpha^{2}-M^{2}\left[\gamma\left(\alpha^{2}-1\right)+1\right]\right\}^{2}}{M^{4}\left[\gamma\left(2 \alpha^{2}-1\right)+1\right]^{2}}+\frac{2 \gamma\left(\alpha^{2}-1\right)}{M^{2}\left[\gamma\left(2 \alpha^{2}-1\right)+1\right]}}
\end{aligned}
$$

Temperature ratio:

$$
\frac{T_{g 1}}{T_{g 2}}=\frac{P_{g 2} \rho_{g 1}}{P_{g 1} \rho_{g 2}},
$$

where $T_{g 1}, T_{g 2}$ - the temperatures before and after the shock wave in pseudo-gas from abrasive granules, $\alpha-$ the reciprocal of the recovery factor $-\beta=\sqrt{\frac{1-f}{1+f}}$, where $f$ - the dry friction coefficient (all variables with index 1 correspond to the values before the shock, with index 2 after the shock wave).

Figures 1 and 2 show the graphs of the above ratios (12) - (15) compared to the ratios for ideal gas $(7)-(10)$. 


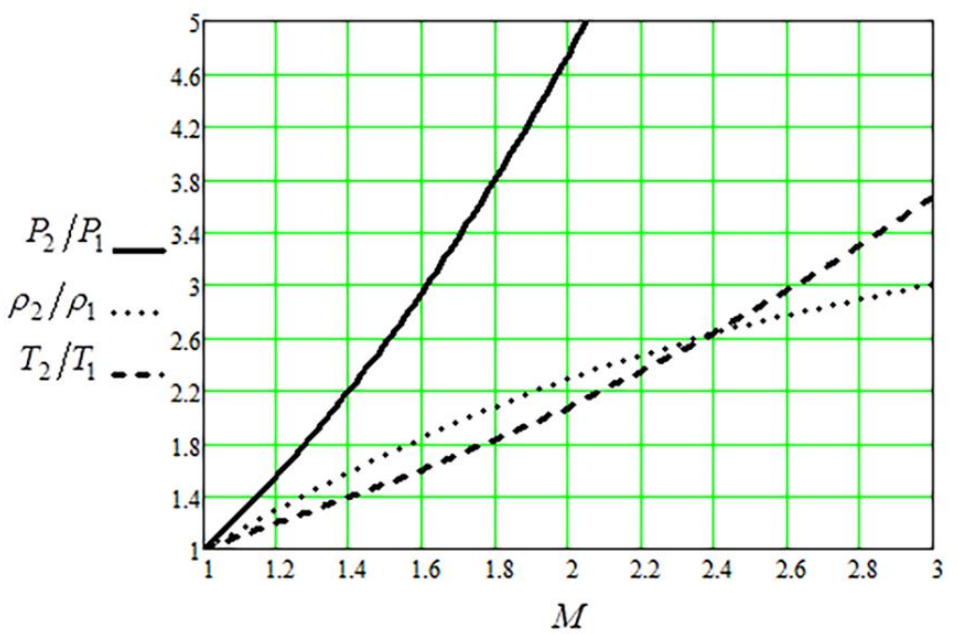

Figure 1 - Dependences of ratios of the pressure, density, and temperature of the gas after and before the shock wave as a function of the Mach number

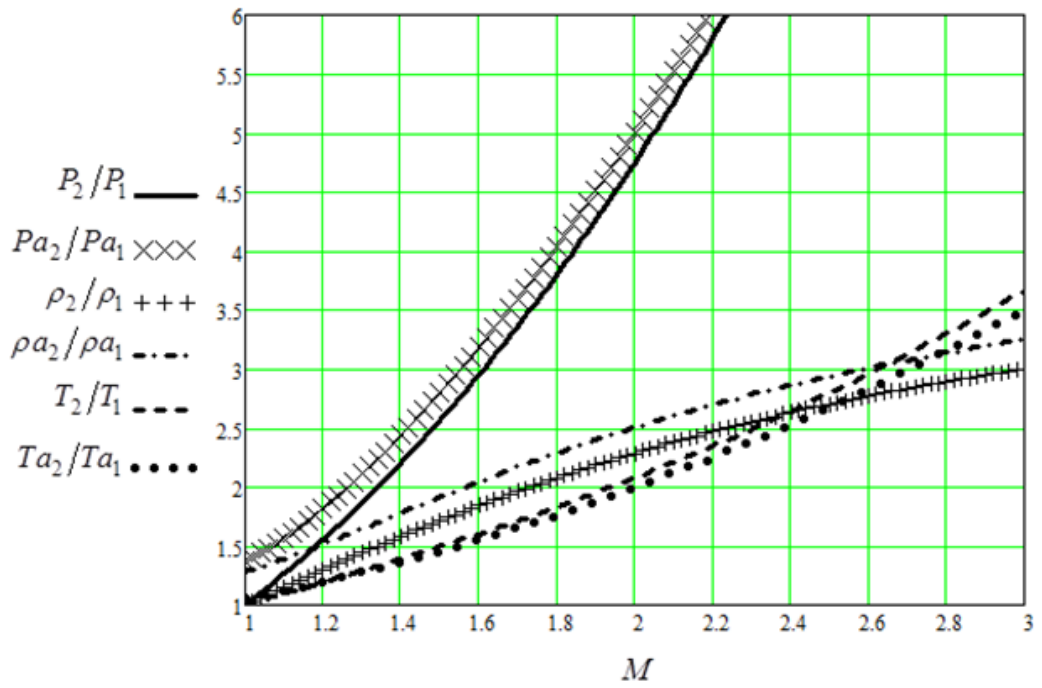

a) 


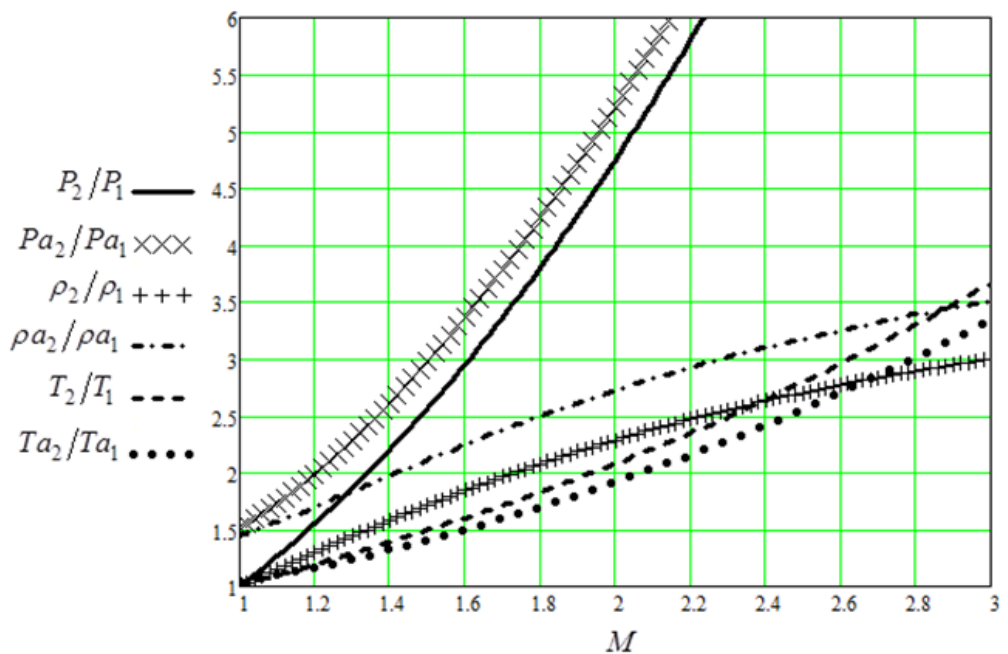

b)

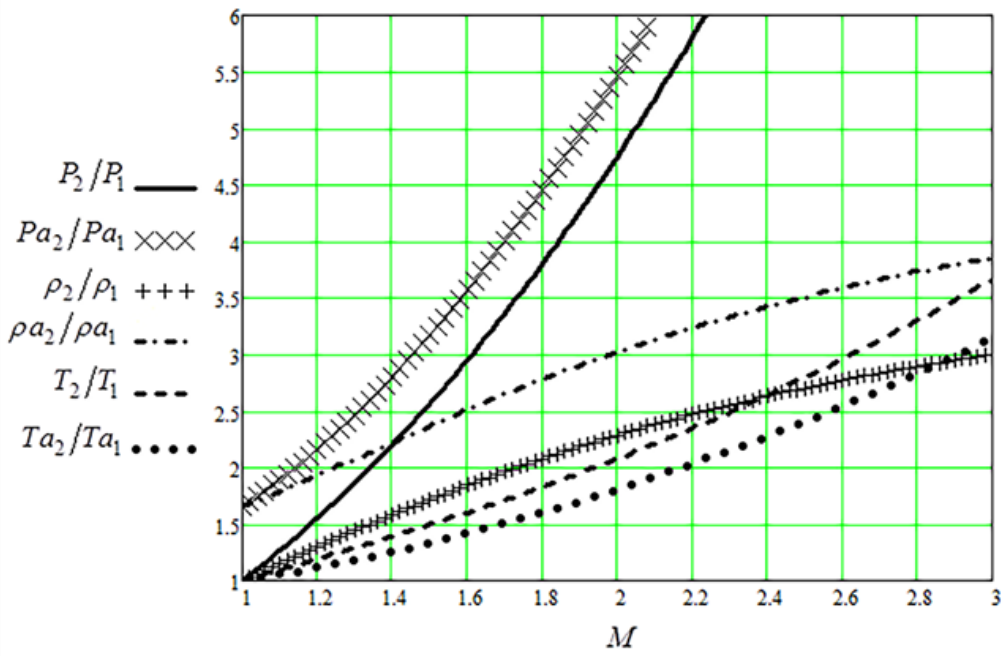

c)

Figure 2 - Dependences of the ratios of pressures, densities and temperatures of pseudogas and ideal gas before and after the shock wave in inelastic collision on the Mach number: (a) $-\alpha=1.03$; (b) $-\alpha=1.066$; (c) $-\alpha=1.1$

In all the graphs in Figure 3, the pressure and density ratios at the beginning of the coordinates (with the Mach number equal to one) exceed a value equal to 
one, as should be in the case for an ideal gas. This is due to the fact that inelastic collisions of granules with the surface of the part lead to a loss of the kinetic energy of the granules after the collision. Pseudo-gas "cools" near the surface of the parts. This leads to a decrease in the speed of sound in this volume and, therefore, a shock wave occurs on the surface of the parts at a speed lower than the speed of sound in the pseudo-gas of abrasive granules $(C \approx 0.745 A \omega)$. It can be seen from the figure that the ratio $T_{g 1} / T_{g 2}$ is less than unity at the speeds of parts less than the speed of sound.

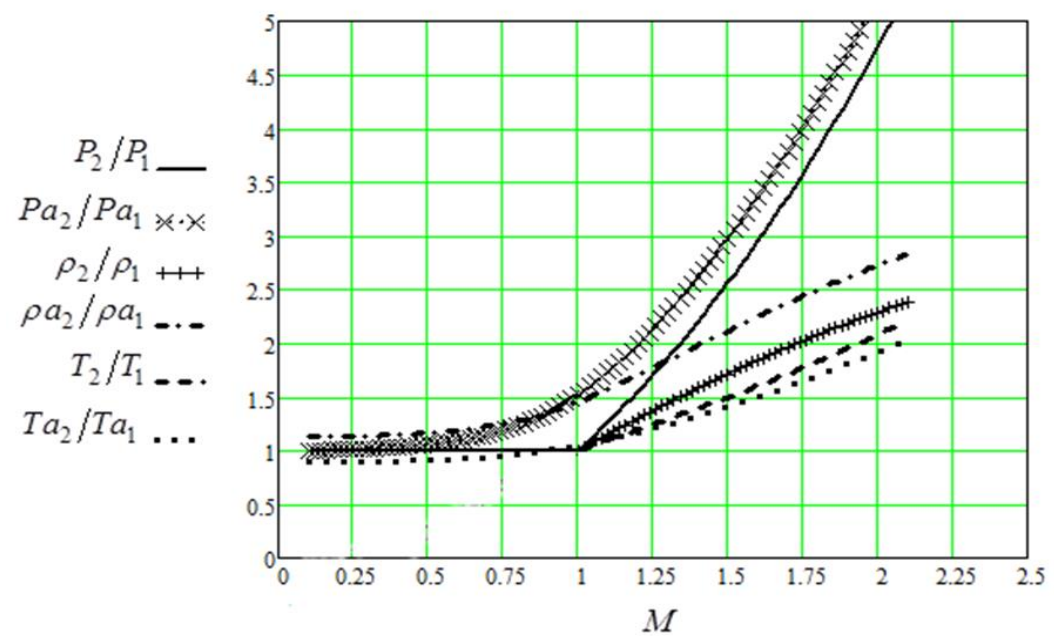

Figure 3 - Ratios $P_{g 2} / P_{g 1}, \rho_{g 2} / \rho_{g 1}, T_{g 2} / T_{g 1}$ at Mach numbers in pseudo-gas from abrasive granules at a considerable distance from the surface of the part, $\alpha=1.06$

When the processed parts exceed the speed of sound in the pseudo-gas, it is necessary to enter into the formula for calculating metal removal during vibration processing a correction directly proportional to the ratio $\rho a_{2} / \rho a_{1} \sqrt{T a_{2} / T a_{1}}$. The obtained dependences of the values of the correction factor $K=\rho a_{2} / \rho a_{1} \sqrt{T a_{2} / T a_{1}}$ on the Mach number, which is equal to the ratio of the speed of movement of the processed parts to the speed of sound in the abrasive granules pseudo-gas, for various coefficients $\alpha$ are presented graphically in Fig. 4 .

The obtained dependences of the values of the correction factor $K=\rho a_{2} / \rho a_{1} \sqrt{T a_{2} / T a_{1}}$ on the Mach number, equal to the ratio of the speed of 
movement of the processed part to the speed of sound in the abrasive granules pseudo-gas, for various factors $\alpha$ are presented graphically (Fig. 4).

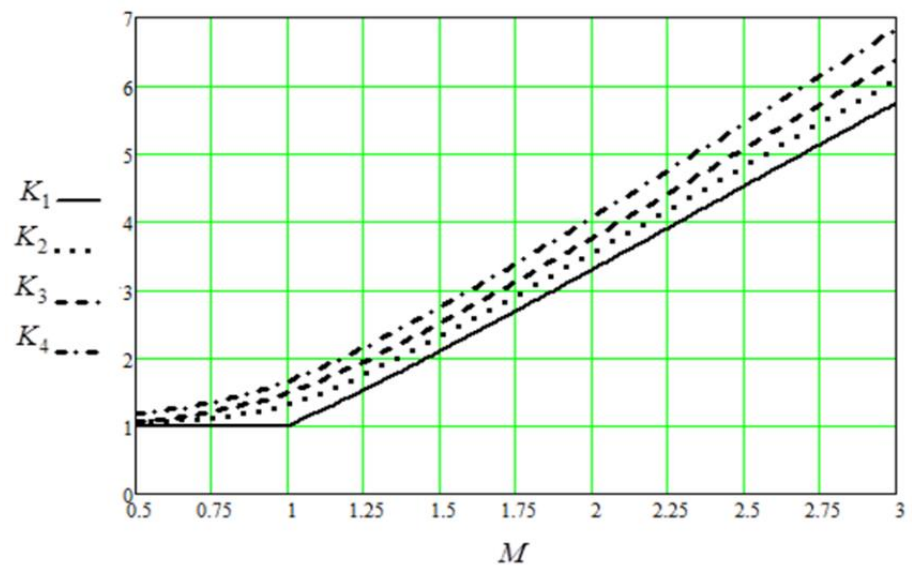

Figure 4 - Dependences of the correction factor $\mathrm{K}$ on the Mach number:

$\mathrm{K} 1-\alpha=1 ; \mathrm{K} 2-\alpha=1,03 ; \mathrm{K} 3-\alpha=1,06 ; \mathrm{K} 4-\alpha=1,1$

Then, the curves of metal removal during vibration processing of parts, calculated using the above formulas, were obtained, depending on the amplitude of the reservoir oscillations (Fig. 5). The curve marked with letter $Q$ is constructed without taking into account the occurrence of a shock wave in the pseudo-gas of abrasive granules. Curves $Q_{1}, Q_{2}, Q_{3}, Q_{4}$ are constructed taking into account the appearance of a compressed layer on the surface of parts for different coefficients $\alpha: \alpha_{1}=1 ; \alpha_{2}=1.03 ; \alpha_{3}=1.06 ; \alpha_{4}=1.1$.

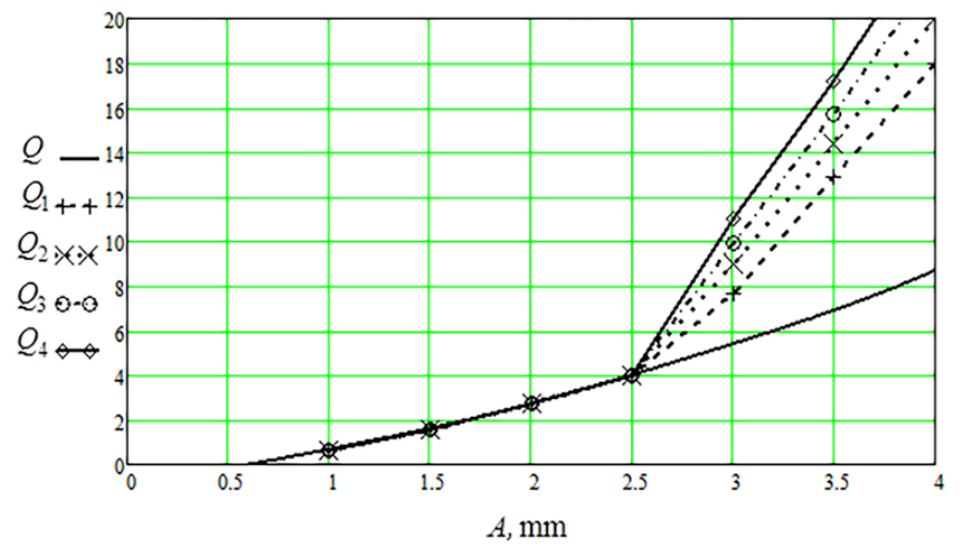


Figure 5 - Dependences of metal removal on the amplitude of reservoir oscillations at an oscillation frequency of $30 \mathrm{~Hz}$ without and taking into account the occurrence of a shock wave in the pseudo-gas of abrasive granules $\left(Q_{1}, Q_{2}, Q_{3}, Q_{4}\right)$

The above formulas were used to calculate metal removal curves during vibration treatment of parts depending on the oscillation frequency of the reservoir (Fig. 6). The curve denoted by letter $Q$ is constructed without taking into account the occurrence of a shock wave in the pseudo-gas of abrasive granules. Curves $Q_{1}, Q_{2}, Q_{3}, Q_{4}$ are constructed taking into account the appearance of a compressed layer on the surface of parts for different coefficients $\alpha: \alpha_{1}=1 ; \alpha_{2}=1.03 ; \alpha_{3}=1.06 ; \alpha_{4}=1.1$.

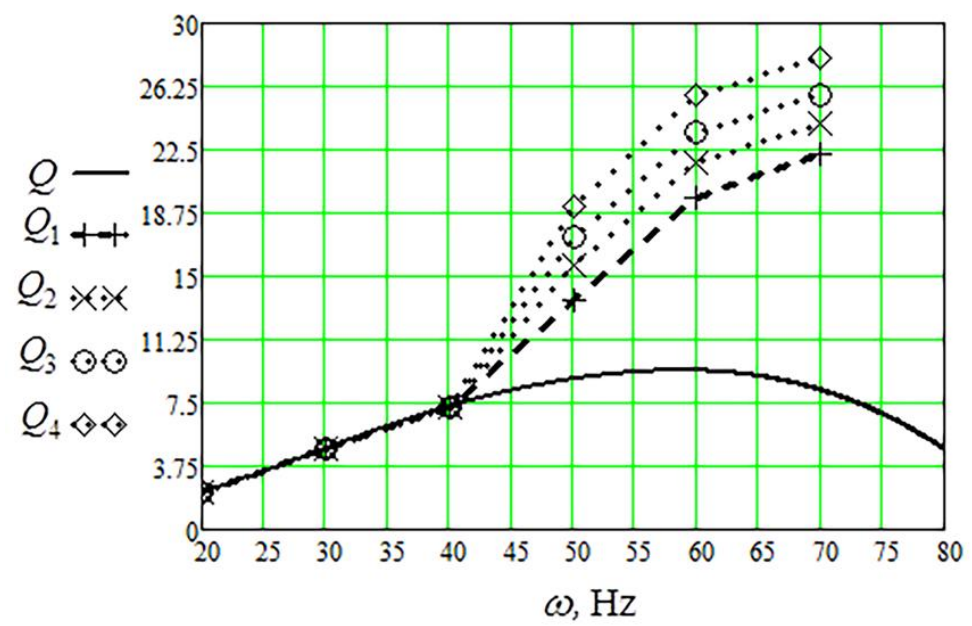

Figure 6 - Dependences of metal removal on the oscillation frequency of the reservoir at an oscillation amplitude of $2.5 \mathrm{~mm}$ without and taking into account the occurrence of a shock wave in the pseudo-gas of abrasive granules $\left(Q_{1}, Q_{2}, Q_{3}, Q_{4}\right)$

In the course of experiments according to multi-energy technologies for the vibrational processing of body brass parts of hydraulic-pneumatic systems the parts were processed "with fixation" in an appliance performing autonomous movement independent of the reservoir $[6,7]$. In this case, the following pattern was discovered. In the case of exceeding the amplitude of oscillations of the processed parts, which are oscillating, like a reservoir with an amplitude of $2.5 \mathrm{~mm}$ and a frequency of $34 \mathrm{~Hz}$, a noticeable increase in metal removal is fixed. That is, the curve of the dependence of metal removal undergoes a break (Fig. 7). The graph 
shows that the curve has a break, which cannot be explained by the experimental error. The experimental error is shown with crosses.

An experimental dependence of metal removal on the vibration frequency of brass parts in the appliance, which performs an autonomous movement independent of the reservoir, has been also obtained. In this case, the oscillation frequency of the reservoir is $43 \mathrm{~Hz}$, the amplitude of the reservoir oscillations is $2.5 \mathrm{~mm}$ (Fig. 8).

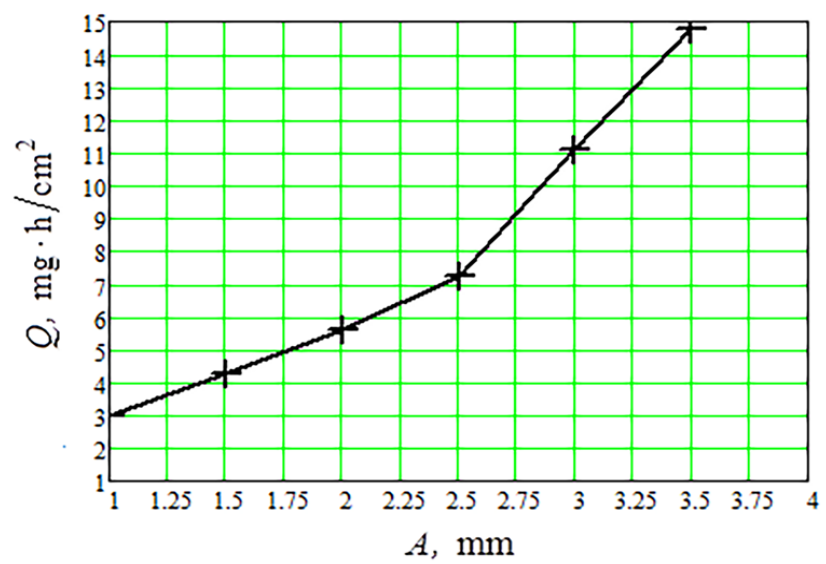

Figure 7 - Dependence of metal removal during vibration treatment of brass parts on the amplitude of their autonomous movement: " + " - the value of the experimental error

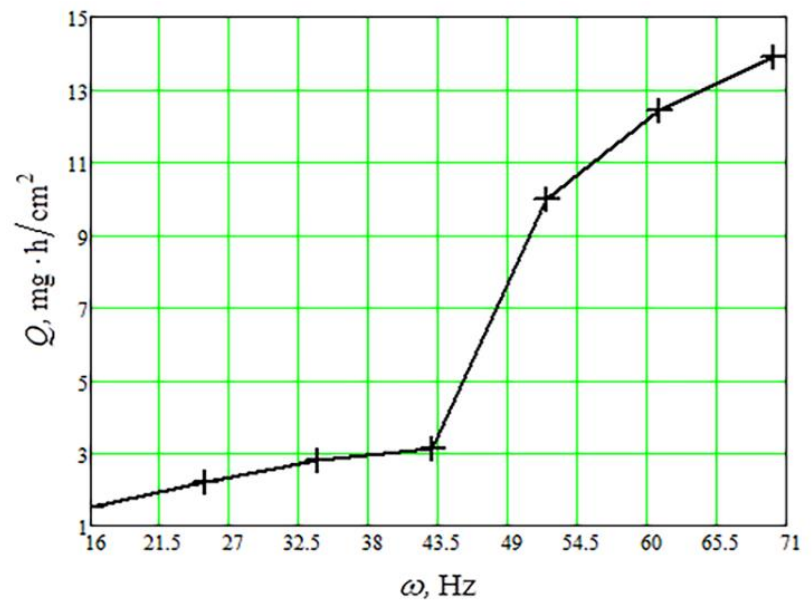


Figure 8 - Dependence of metal removal during vibration treatment of brass parts on the frequency of their autonomous movement: "+" - the value of the experimental error

Obviously, at a vibration frequency of parts exceeding $43 \mathrm{~Hz}$, the curve of metal removal dependence on frequency, as in the previous case, undergoes a break. This behavior of both curves corresponds to a significant change in the metal removal mechanism with varying parameters of the autonomous movement of parts independent of the reservoir. It is possible to explain this phenomenon by the fact that the abrasive granules are concentrated near the treated surfaces of oscillating parts. This is due to the impossibility of transmitting the force pulse to the working medium layers remote from the parts, since the speed of the parts exceeds the speed of propagation of the power pulse in the abrasive granules pseudo-gas. Under these conditions, the speed of the chaotic movement of the working medium and their concentration near the surfaces of the processed parts increases sharply. As a result, it leads to the intensification of their processing.

Comparison of the calculated dependences (Fig. 5, 6) with the experimental (Fig. 7,8 ) indicates the validity of the hypothesis about the possibility of shock waves of an oscillating working medium in the pseudo-gas from abrasive granules, despite the fact that the behavior of the curves (Fig. 5, 6) and (Fig. 7, 8) is rather qualitative than quantitative.

\section{Conclusions}

1. During vibration treatment using multi-energy technology, parts move autonomously under the influence of additional energy action. However, an effect similar to a shock wave can occur in an oscillating working medium. For such a physical situation, an analogy is carried out between the ratios of the thermodynamic parameters of the pseudo-gas before and after the shock wave, which are described by the Hugoniot adiabat.

2. One of the main differences in the behavior of pseudo-gas from abrasive granules is that the collisions between the abrasive granules and the surface of the parts are inelastic. When the abrasive granules collide, the power impulse is lost. These losses are forced and have a negative effect on the vibration treatment process, since the collisions of granules with the surface of the processed parts cause metal removal, and they are a practical result of vibration treatment.

3. Modeling of the compressed layer of the oscillating working medium near the surfaces of the processed parts installed in the device and moving autonomously from the reservoir was carried out taking into account the losses of the power impulse of the granules when they collide with the parts. The introduction of the recovery factor into the equation of conservation of the total energy of the gas in combination with the Navier-Stokes equations and the continuity equation refines the expression for the Hugoniot adiabat as applied to an 
abrasive granules pseudo-gas. This makes it possible to obtain expressions relating the pressure in the pseudo-gas, its density and temperature before and after the shock wave. The obtained ratios make it possible to explain the experimentally established regularity of an increase in metal removal when the frequency and (or) the amplitude of autonomous vibrations of parts during vibration processing are exceeded.

4. Analysis and experimental studies of the appearance of an effect similar to a shock wave in an abrasive granules pseudo-gas allow:

- To intensify the process of vibration treatment of parts by using multienergy technologies.

- To optimize the amplitude-frequency characteristics of oscillations of the vibrating machine reservoir and autonomously moving parts in relation to the achievement of the required technological result.

- To optimize the amplitude-frequency characteristics of the autonomous movements of the processed parts and the vibrating machine reservoir, depending on the spatial arrangement of the parts in the volume of the reservoir.

- To optimize the amplitude-frequency characteristics of the autonomous movements of the processed parts and the reservoir of the vibrating machine, depending on the shape and number of simultaneously processed parts.

References: 1. Mamalis A.G., Grabchenko A.I., MitsykA.V., $\quad$ Fedorovich V.A., $\quad$ KundrákJ. Mathematical simulation of motion of working medium at finishing - grinding treatment in the oscillating reservoir. The International Journal of Advanced Manufacturing Technology 70, p. $263-$ 276 (2014). DOI: https://doi.org/10.1007/s00170-013-5257-6 2. Mitsyk A.V. Opredelenie vlijanija parametrov vibroobrabotki na velichinu davlenija granul i detalej // Vibracii v tehnike i tehnologijah. 2010. 3(59). s. 75 - 79. 3. Mitsyk A.V., Fedorovich V.A. Puti intensifikacii vibracionnoj otdelochnozachistnoj obrabotki kombinirovaniem shem jenergeticheskih vozdejstvij na rabochuju sredu i detali // Aviacionno-kosmicheskaja tehnika i tehnologija. 2011. № 6. s. 26-34. 4. Kundrák J., Morgan M., Mitsyk A.V., Fedorovich V.A. The effect of the shock wave of the oscillating working medium in a vibrating machine's reservoir during a multi-energi finishing-grinding vibration processing. The International Journal of Advanced Manufacturing Technology 106, p. 4339 - 4353 (2020). DOI: https://doi.org/10.1007/s00170-019-04844-2 5. Matveev A.N. Molecular Physics. Mir Publishers: Moscow, Russia, 1985. p. 450. 6. Pat. na korisnu model' № 133705 Ukraina, MPK V24V 31/06. Sposib vibroobrobki detalej / Mitsyk A.V; zajavnik ta patentoobladach SNU im. V. Dalja. № u201808772; zajavl. 16.08.2018; opubl. 25.04.2019, Bjul. № 8. 7. Pat. na korisnu model' № 133708 Ukraina, MPK V24V 31/06. Sposib ozdobljuval'no-zachishhuval'noï obrobki vil'nim abrazivnim seredovishhem / Mitsyk A.V; zajavnik ta patentoobladach SNU im. V. Dalja. № u201808775; zajavl. 16.08.2018; opubl. 25.04.2019, Bjul. № 8 . 
Андрій Міцик, Володимир Федорович, Анатолій Грабченко, Харків, Україна

\title{
ЕФЕКТ УДАРНОЇ ХВИЛІ В КОЛИВНОМУ РОБОЧОМУ СЕРЕДОВИЩІ ПРИ ВІБРАЦІЙНІЙ ОЗДОБЛЮВАЛЬНО-ЗАЧИЩУВАЛЬНІЙ ОБРОБЦІ
}

\begin{abstract}
Анотація. Розглянуто поширення силового імпульсу в робочому середовищі як $у$ псевдогазі, тобто подібно поширенню акустичного збурення. Встановлено відповідність між кінетичною енергією гранул, їх імпульсом і термодинамічними параметрами температури й тиску. Проаналізовано ефекти руху оброблюваних деталей зі швидкостями близькими до швидкостей переміщення гранул абразиву. Розглянуто рух деталей в робочому середовищі. Визначено ефект слабкої ударної хвилі - стрибок ущільнення в псевдогазі з абразивних гранул. Визначено вплив виникнення стрибка ущільнення на процес віброобробки. Розглянуто механізм виникнення слабкої ударної хвилі в середовищі, що коливається. Записано рівняння Нав'є-Стокса в одновимірному випадку до і після стрибка ущільнення. Визначено рух деталей в робочому середовищі. Розглянуто механізм виникнення слабкої ударної хвилі, тобто стрибок ущільнення у псевдогазі з абразивних гранул. Встановлено характер взаємодї поверхонь резервуару з оброблюваними деталями та гранулами робочого середовища. Встановлено зменшення кінетичної енергії псевдогазу з гранул абразиву в результаті зіткнення з поверхнею оброблюваних деталей, що веде до зміни тиску і щиільності відповідно до рівняння Менделєєва-Клапейрона. Приведено відношення температур після стрибка ущільнення і до нього через відношення тисків $i$ щиільності. Дана характеристика адіабати Гюгоньо для псевдогаза з гранул робочого середовища. Отримано знімання металу при віброобробиі деталей в залежності від амплітуди та частоти коливань резервуару. Виявлено зміну механізму знімання металу при варіюванні параметрів автономного руху резервуару та оброблюваних деталей. Розраховано, що швидкість хаотичного руху середовища поблизу оброблюваних поверхонь різко зростає $і$ призводить до інтенсифікаиіі обробки деталей. Встановлено адекватність теоретичних $i$ експериментальних досліджень.
\end{abstract}

Ключові слова: віброобробка; робоче середовище; оброблювані деталі; силовий імпульс; ударна хвиля; стрибок ущільнення; кінетична енергія; термодинамічні параметри. 